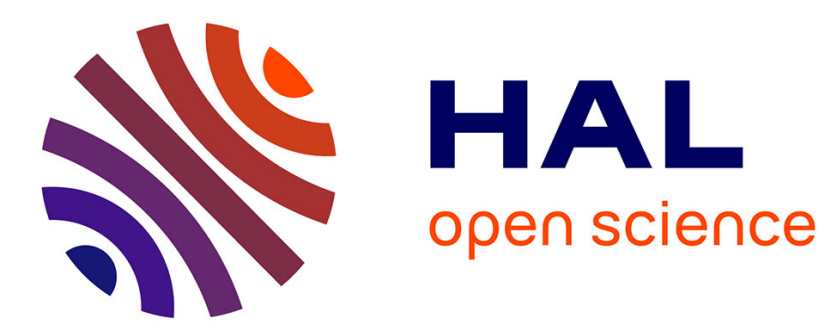

\title{
RECOMBINATION MECHANISM AT DISLOCATIONS IN GaAs EBIC CONTRAST STUDY
}

B. Sieber, J. Farvacque

\section{To cite this version:}

B. Sieber, J. Farvacque. RECOMBINATION MECHANISM AT DISLOCATIONS IN GaAs EBIC CONTRAST STUDY. Journal de Physique IV Proceedings, 1991, 01 (C6), pp.C6-35-C6-37. 10.1051/jp4:1991606 . jpa-00250691

\section{HAL Id: jpa-00250691 https://hal.science/jpa-00250691}

Submitted on 1 Jan 1991

HAL is a multi-disciplinary open access archive for the deposit and dissemination of scientific research documents, whether they are published or not. The documents may come from teaching and research institutions in France or abroad, or from public or private research centers.
L'archive ouverte pluridisciplinaire HAL, est destinée au dépôt et à la diffusion de documents scientifiques de niveau recherche, publiés ou non, émanant des établissements d'enseignement et de recherche français ou étrangers, des laboratoires publics ou privés. 


\section{RECOMBINATION MECHANISM AT DISLOCATIONS IN GaAs EBIC CONTRAST STUDY}

\section{B. SIEBER and J.L. FARVACQUE}

Laboratoire de Structure et Propriétés de l'Etat Solide, URA 234, Bâtiment C6, Université des Sciences et Techniques de Lille Flandres-Artois, F-59655 Villeneuve d'Ascq Cedex, France

Dislocations located in the space charge region of a Schottky diode are recombination centers for electron hole pairs. We assume that minority carriers created within a region where the dislocation electrical field is larger than the Schottky field are recombined at the dislocation line. Therefore, a capture cylinder radius can be defined by the criterium

$$
\left|\mathrm{E}_{\text {dislocation }}\right|=\left|\mathrm{E}_{\text {Schottky }}\right|
$$

Quantitative values of the EBIC contrast have been calculated on this assumption. We only deal with electrical fields associated with the charged line of the dislocation. The screening charge, solution of the Poisson's equation, is numerically calculated. The radius of the cylinder, which is selfconsistently calculated, depends on the doping level of the specimen, on temperature, electron beam intensity and on dislocation characteristics: its capture crosssection and its energy level position in the band gap.

The numerical values and their dependences with beam intensity are compared with experimental values obtained on $\alpha$ and $\beta$ dislocations freshly introduced in a bulk $n$ type $\left(N_{d}=5.10^{16} \mathrm{~cm}^{-3}\right)$ GaAs specimen. In order to localize the generation of electron hole pairs within the SCR of the Schottky diode, an accelerating voltage of $8 \mathrm{kV}$ and an applied reverse bias of $1.5 \mathrm{~V}$ have been used.

The numerical EBIC values are similar to the experimental ones (2-3\%) when the influence of the electron beam intensity is not taken into account (figure 1 and table 1). 

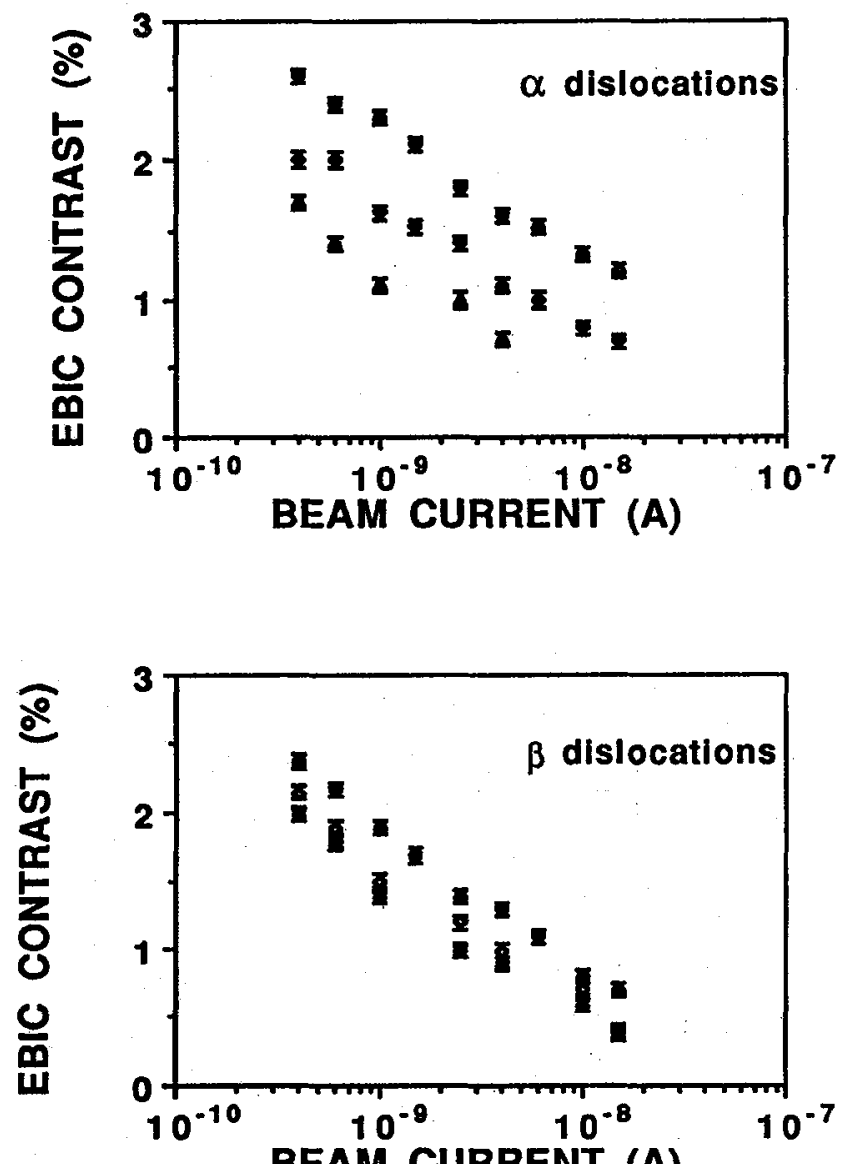

Figure 1: Experimental EBIC contrast curves in the SCR as a function of beam intensity. $\alpha$ and $B$ dislocations perpendicular to the surface.

The introduction, in the calculations, of the saturation effect leads to EBIC contrast values much lower than the experimental ones (by about a factor 20), whatever is the capture cross section in the range $10^{-16}-10^{-14} \mathrm{~cm}^{2}$ (table 1 ). Such numerical values would lead, in our experiments, to unobservable dislocations, and to the same contrast values for $\alpha$ and $\beta$ dislocations. But, from many contrast curves as a function of beam intensity recorded at $30 \mathrm{kV}$, it was 
shown that the average contrast of $\alpha$ dislocations is a little higher than that of $\beta$ dislocations [1].

\begin{tabular}{|c|c|c|c|c|c|}
\hline \multicolumn{3}{|c|}{ NO SATURATION } & \multicolumn{3}{|c|}{ SATURATTON } \\
\hline \multirow[t]{2}{*}{ Ed (ey) } & \multirow{2}{*}{$\begin{array}{c}R(z=W) \\
n m\end{array}$} & \multirow{2}{*}{$\begin{array}{c}\text { EBIC } \\
\text { CONTRAST } \\
(\%)\end{array}$} & \multirow{2}{*}{$\begin{array}{l}\text { Capture } \\
\text { cross-section } \\
\text { (cm2) }\end{array}$} & \multirow{2}{*}{$\begin{array}{l}\text { Beom } \\
\text { Intensity } \\
\text { (A) }\end{array}$} & \begin{tabular}{|c} 
EBIC Contrast \\
$(\mathscr{(})$
\end{tabular} \\
\hline & & & & & $E d=0.2-0.6 \mathrm{ev}$ \\
\hline 0.2 & 81 & 2.6 & $10^{-16}$ & $\begin{array}{l}10-12 \\
10-11 \\
10-10\end{array}$ & $\begin{array}{l}0.1 \\
0.06 \\
0.029\end{array}$ \\
\hline 0.6 & 67 & 1.2 & & $\begin{array}{l}10^{-9} \\
10^{-8}\end{array}$ & $\begin{array}{l}0.024 \\
0.0034\end{array}$ \\
\hline & & & $10^{-14}$ & $\begin{array}{l}10-12 \\
10-11 \\
10-10 \\
10-9 \\
10-8\end{array}$ & $\begin{array}{l}0.225 \\
0.16 \\
0.105 \\
0.06 \\
0.03 \\
\end{array}$ \\
\hline
\end{tabular}

Table 1: Theoretical EBIC contrast in the SCR for different dislocation energy levels in the band gap. $R$ is the radius of the screening cylinder. $W$ is the SCR width.

These discrepancies suggest that, in GaAs, the thermal jump of majority carriers over the barrier is not the limiting process for electron hole pairs recombination. We propose that there is a free carrier current along the dislocation line.

[1] P. CARTON, Thèse, Université de Lille (1990) 